\title{
Is green the new gold? Venture capital and green entrepreneurship
}

\author{
Boris Mrkajic • Samuele Murtinu • Vittoria G. Scalera
}

Accepted: 30 June 2017 / Published online: 7 October 2017

(C) The Author(s) 2017. This article is an open access publication

\begin{abstract}
We test whether born-to-be-green represents a signal toward potential venture capital (VC) investors on a sample of Italian, independent, unlisted, high-tech entrepreneurial firms. We employ several identification strategies by controlling for the major potential signals and the alleged selection bias between green and nongreen entrepreneurs. We exploit firm-level information about the "active search for VC financing." Alternatively, we exploit the cross-local community variation in the awareness about environmental issues in an instrumental variable setting. Our results show that neither running a business based on green technologies nor positioning a business in a green sector per se are strongly correlated with the likelihood to get VC. Instead, we find that born-to-be-green can be a reliable signal for investors only when entrepreneurs perform activities based on green technologies/products and position their business in a green sector, at the same time. Further, we present three contingencies that moderate
\end{abstract}

\section{B. Mrkajic}

Politecnico di Milano School of Management, Via R.

Lambruschini 4b, 20156 Milan, Italy

e-mail: boris.mrkajic@polimi.it

\section{S. Murtinu $(\bowtie)$}

Faculty of Economics and Business, Department of Innovation Management \& Strategy, University of Groningen, Nettelbosje 2, 9747 AE Groningen, The Netherlands

e-mail: s.murtinu@rug.nl

V. G. Scalera

University of Amsterdam Business School, Plantage Muidergracht 12, 1018 TV Amsterdam, Netherlands

e-mail: v.g.scalera@uva.nl the association between green business propositions and the likelihood to get VC, namely the technical/scientific education of the founder(s), the origin of the firm as academic spin-out, and the presence of corporate shareholders into the venture's equity. The paper offers relevant managerial implications.

Keywords Entrepreneurship - Green ventures · Venture capital · Signal · Green technology · Green product

JEL classifications $\mathrm{G} 24 \cdot \mathrm{L} 26 \cdot \mathrm{M} 13 \cdot \mathrm{M} 21 \cdot \mathrm{O} 35 \cdot \mathrm{Q} 55$

\section{Introduction}

The contribution of entrepreneurship to the real economy is well documented (Audretsch 1995; Tamvada 2009). On the one hand, entrepreneurial firms enhance competition in oligopolistic industries, and thus discipline the market power of big incumbents (Kirzner 1997). On the other hand, entrepreneurial firms - especially when operating in high-tech industries - increase the incentives of big companies to invest in R\&D projects, which are responsible for introducing product and process innovations in the market at a faster pace (Schumpeter 1934, 1939).

Among other positive contributions to the economy and the society, entrepreneurship has been mentioned as one of the most effective solutions for solving many social and environmental concerns (Berle 1991; Demirel and Parris 2015). In fact, entrepreneurship can foster sustainable development, leveraging the 
orientation of entrepreneurs toward break-through innovation, technology, risk-taking propensity, and flexibility (Hoogendoorn et al. 2015; Miller 1983; Wiklund 1999; Zahra 1993). Green ventures represent a way through which entrepreneurship can fulfill the call for a greener and more environment-friendly business orientation, providing practical and innovative solutions to environmental problems (Criscuolo and Menon 2015; Esty and Winston 2009).

As a result, the number of born-green ventures is growing fast, leveraging both economic and environmental benefits, and such ventures have attracted the attention of both policy makers and venture capitalists (VCs) (Ghosh and Nanda 2010). However, while the existing entrepreneurship literature has already offered some insights on the main features and specificities of green ventures (Hall and Helmers 2010; Meek et al. 2010; Meyskens and Carsrud 2013; Pacheco et al. 2010), scant attention has been devoted to understand their ability to access external finance and whether (and how) their characteristics may act as market signals for external financiers.

This is fairly surprising as ever since the works of Schumpeter (1934, 1939), access to financial resources has been identified as a critical determinant of technological innovation, which has been found to be the case for green technologies as well (Amore and Bennedsen 2016). Even though policy makers have implemented an array of public policies to subsidize and foster the development of environment-friendly businesses (Bürer and Wüstenhagen 2009; Criscuolo and Menon 2015), born-green new ventures still face severe capital constraints, at least comparable to the ones of all the other new high-tech innovative ventures. The barriers are caused by the existence of information asymmetries between ventures and capital markets, particularly the credit ones (Hall and Lerner 2010). Debt capital providers are typically not able to cope with the above challenge and rarely engage in financing high-tech ventures, which results in venture capital (VC) firms being the most suitable financial intermediary to provide capital to (high-tech) entrepreneurial firms (Gompers and Lerner 2001).

Nevertheless, the overall VC supply is still rather limited (Kaplan and Lerner 2016), especially in Southern Europe (EVCA 2015). Ventures thus need to compete for the scarce financial resources and signal their quality to potential investors (Connelly et al. 2011). By doing that, they can distinguish themselves from the pool of other ventures and secure the investment of private investors (e.g., VCs).

Our work contributes to the literature at the nexus between entrepreneurship and finance (e.g., Bürer and Wüstenhagen 2009; Criscuolo and Menon 2015; delPalacio et al. 2012), aiming at understanding whether born-to-be-green represents a signal toward potential VCs. In other words, all other things being equal, is there a higher likelihood to receive $\mathrm{VC}$ when the focal venture is born-to-be-green?

Leveraging theoretical arguments from entrepreneurial finance and (green) entrepreneurship literature, we argue that, for high-tech ventures, born-to-be-green may theoretically entail either a positive or a negative signal toward VCs. On the one hand, VCs may more likely invest in green ventures, compared to other high-tech ventures, because green activities represent emerging and promising businesses, also legitimated by media and governments (Petkova et al. 2014). On the other hand, green ventures may lead to higher risk, uncertainty, and (both technical and managerial) complexity, compared to the other high-tech ventures, due to the nature of the environmental technologies and the infant stage of the sector (e.g., Criscuolo and Menon 2015; Ghosh and Nanda 2010).

To provide an answer to our research question, we use a sample of Italian entrepreneurial firms founded between 1983 and 2008 and extracted from the RITA (Research on Entrepreneurship in Advanced Technologies) dataset. To test the likelihood to receive VC finance - so assessing the efficacy of the born-tobe-green signal - our econometric methodology employs several identification strategies to avoid the overestimation of the potential signaling effect of green businesses on the access to VC finance. Our results show that running a business based on green technologies/products per se is not correlated with the likelihood to receive VC. However, we do find that entrepreneurs who run a green business and position their venture in a green sector are more likely to get VC funding: the estimated marginal effect is $+7 \%$.

\section{Green ventures and VC financing}

We refer to green ventures as high-tech ventures using green technologies in their businesses or offering green products/services. As such, green technologies comprise a wide range of innovations, including renewable 
energy resources, technologies using renewable energy sources, energy storage, distribution and management technologies, recycling and waste technologies, industrial processes, and technologies for capture, storage, and treatment or disposal of greenhouse gases (Hall and Helmers 2010). More broadly, green technologies are defined as technologies that provide, directly or indirectly, environmental benefits when compared to the traditionally used technologies that they are supposed to substitute (Hall and Helmers 2013). ${ }^{1}$

As regards green products/services, they are well defined by Ottman et al. (2006) who refer to products/ services "that strive to protect or enhance the natural environment by conserving energy and/or resources and reducing or eliminating use of toxic agents, pollution, and waste" (p. 24). As also pointed out by Roy et al. (1996), the plethora of green products/services includes a spectrum of solutions aimed at tackling environmental issues ranging from natural resources waste to energy efficiency and pollution (for a more detailed conceptual framework, see Dangelico and Pujari 2010; for further definitions and classifications of green products, see Dangelico and Pontrandolfo 2010).

Despite the fact that green technologies and products/ services have been under development for the last couple of decades, the so-called green sector is still argued to be in its nascent stage in terms of commercialization and market acceptance (Petkova et al. 2014). The green paradigm has gained a prominent relevance relatively recently with the urgency of climate change and severe depletion of natural resources. ${ }^{2}$

Green entrepreneurship represents a mechanism through which entrepreneurship can address the need for greener and more environment-friendly business activities (Dean and McMullen 2007; Pacheco et al. 2010; York and Venkataraman 2010). ${ }^{3}$ Indeed, entrepreneurs are argued to be the key actors for spurring sustainable development, leveraging their assertiveness and

\footnotetext{
${ }^{1}$ For instance, in terms of patents as defined by the International Patent Classification (IPC), "green" refers to any environmentally sound technologies (EST) that protect the environment, are less polluting, use all resources in a more sustainable manner, recycle more of their wastes and products, or handle residual wastes in a more sustainable manner than the technologies for which they are substitutes (United Nations Framework Convention on Climate Change 2006).

${ }^{2}$ Scholars have been using green and clean terms interchangeably to refer to the same set of technologies (e.g. Hall and Helmers 2010, 2013).

${ }^{3}$ Green entrepreneurship is sometimes referred to as ecopreneurship (e.g. Dixon and Clifford 2007).
}

propensity to engage in innovative, uncertain, and risky activities (Cohen and Winn 2007; Hall et al. 2010; Hockerts and Wüstenhagen 2010).

Even though the literature on this topic is relatively new, it has empirically investigated several themes related to green entrepreneurship, and more broadly to sustainable entrepreneurship (e.g., Meek et al. 2010; Meyskens and Carsrud 2013; Parrish 2010; Sine and Lee 2009). Notwithstanding, insufficient attention has been dedicated to understand the ability of born-green ventures to access external finance (Demirel and Parris 2015), and whether (and how) their characteristics may act as market signals for external financiers. This financing issue appears to be extremely relevant because the born-green entrepreneurial ventures are capital constrained, in spite of favoring regulations and active governmental support directed to environment-friendly businesses (Bürer and Wüstenhagen 2009; Criscuolo and Menon 2015). The notorious information asymmetries between high-tech ventures and capital markets (Hall and Lerner 2010), mainly the debt providers, are particularly hefty in the case of born-green ventures. They arise from the lack of ventures' track record (e.g., Ghosh and Nanda 2010), low ratio between tangible assets and total assets (Denis 2004), and particularly complex technologies that are difficult to assess (Amore and Bennedsen 2016).

As a result, creditors are neither sufficiently competent nor willing to bear the inherent technological risk. Instead, VC fund partners might be more capable to mitigate the information asymmetry (Baum and Silverman 2004; Croce et al. 2013; Hellmann 2000), as well as take higher risks and invest in highly innovative and uncertain projects (e.g., Nahata 2008). VC is thus considered to be the most suitable source of capital for high-tech ventures, including the born-green ones. Worldwide VC investments in the green technologies significantly grew between 2004 and 2008 (Knight 2010), while the share of green VC deals as a percentage of all VC deals has risen for an order of magnitude (from 1 to $10 \%$ ) from 1996 to 2010 (Cumming et al. 2013).

Due to the overall limited VC supply (Kaplan and Lerner 2016), born-green ventures are still forced to compete for the scant financial resources and signal their quality to potential investors to maximize the likelihood to access the VC market (Connelly et al. 2011). The extant literature has shown the power of several signals, such as public subsidies (e.g., Colombo et al. 2011; Lerner 1999; Meuleman and Maeseneire 2012), 
patents (Czarnitzki et al. 2014; Hsu and Ziedonis 2008), founders' human capital and their prior business experience (Gimmon and Levie 2010; Mosey and Wright 2007), and alliances (Baum and Silverman 2004).

However, the power and effectiveness of signals strongly depend on the characteristics of the entrepreneurial ventures, as they may leverage different distinctive factors to convey the quality of their businesses. In Table 1, we summarize key factors that differentiate born-green businesses from an "average" high-tech venture. We use these differences to break down both positive and negative characteristics of born-green businesses that might affect the typology and power of their signals toward VCs. Drawing upon the existing entrepreneurial finance and green entrepreneurship literature, the analysis highlights that the born-green businesses may exploit the green effect to have an easier access to VC. In fact, the green nature of ventures' production processes or products can lead to both economic and environmental benefits, may be appealing for ideological and trend reasons, and could be exploited to offer clearly differentiated products (Bocken 2015; Petkova et al. 2014). However, as any other emerging sector or technology, it can also exemplify ambiguity (Santos and Eisenhardt 2009), driving to different opinions of the investors, whose interpretations may range from envisioning great strategic opportunities to foreseeing fatal consequences. The ambiguity creates not only divergent views about the (un)attractiveness of the green businesses, but also in terms of the selection criteria they consider relevant, because of the lack of proven framework to evaluate green ventures' potential (Petkova et al. 2014). In the case of green high-tech ventures, ambiguity is coupled with considerable uncertainty derived from the extremely high (technological and managerial) complexity, the longer investment duration, and the strong reliance on strictly regulated markets characterized by regulatory volatility and unstable prices (Amore and Bennedsen 2016; Demirel and Parris 2015; Petkova et al. 2011, 2014).

\section{Hypotheses development}

In the recent decades, the literature on environmental entrepreneurship and innovation has flourished offering mixed evidence and argumentations.

Ambec and Lanoie (2008) summarize the reasons why it pays to be green, which should in turn make the investments in green businesses appealing as well. They argue that green businesses could have better access to certain markets (e.g., green public purchasing or the "greening" supply chain of incumbents), offer differentiated products and reach niche markets (i.e., customers willing to pay premium prices for environment-friendly products or services), incur revenues from selling green technologies (e.g., out-licensing green patents), improve risk management and their relationship with external stakeholders (e.g., easier value chain inclusion), and lower costs of resources (e.g., energy-efficient production processes) and labor (e.g., people feeling committed to work for a green venture). Ambec and Lanoie (2008) even explicitly advocate the case that the cost of capital is lower for green businesses. These arguments are in line with the Porter's hypothesis that environmental innovation provides opportunity for gaining competitive advantage (Porter and van der Linde 1995), making investments in the green technologies attractive for potentially high return investments.

Furthermore, Petkova et al. (2014) show that VC firms are, on average, more prone to invest in an emerging sector (such as the green sector), if the sector is legitimized. They mention two mechanisms that determine emerging sectors' legitimacy: (positive) media attention and governmental support, which both hold for the green sector. First, Migendt et al. (2013) report an increase in press articles on environmental technology topics and state that during the 2002-2008 period, it was "hot" to invest in such technologies. Second, a myriad of policy tools (e.g., feed-in tariffs, R\&D subsidies) were put in place to support clean energy sectors and other environment-friendly technologies (e.g., Bürer and Wüstenhagen 2009; Demirel and Kesidou 2011). These have contributed to further enhance the legitimacy of the green sector.

To that end, Petkova et al. (2014) assert the desire of reputable VC firms to invest in emerging sectors to capture a potential "next big thing" and meet high expectations of their stakeholders (e.g., limited partners), ${ }^{4}$ which tend to be subsequently emulated by other VC firms, who typically follow the leading trends set by the most reputable ones. The green businesses and related technologies by their nature entail high risks, yet coupled with the promise of

\footnotetext{
$\overline{{ }^{4} \text { Petkova et al. }}$ (2014) quote an interviewed venture capitalist explaining why VCs invest in emerging sectors: “... we [VCs] typically try not to invest in anything that's just going to move the needle a little bit, but that is going to be a completely revolutionary...".
} 
Table 1 Key differences between born-green and non-green high-tech ventures

\begin{tabular}{|c|c|c|}
\hline Factor & Green high-tech ventures & Non-green high-tech ventures \\
\hline $\begin{array}{l}\text { Competences and resources } \\
\text { (Bamberger et al. 1989; Criscuolo and } \\
\text { Menon 2015; Ghosh and Nanda 2010; } \\
\text { Petkova et al. 2014) }\end{array}$ & $\begin{array}{l}\text { - Large managerial slack due to the nascent } \\
\text { stage of sector, i.e. "managerial valley } \\
\text { of death" } \\
\text { - Highly capital intensive (e.g. wind and } \\
\text { solar power) }\end{array}$ & $\begin{array}{l}\text { - Well-developed managerial best-practices } \\
\text { - Not necessarily capital intensive (e.g. software } \\
\text { industry) }\end{array}$ \\
\hline $\begin{array}{l}\text { Technological complexity } \\
\text { (Amore and Bennedsen 2016) }\end{array}$ & - Extremely high technological complexity & - Fairly high technological complexity \\
\hline $\begin{array}{l}\text { VC investment outlook } \\
\text { (Ghosh and Nanda 2010; Knight 2010; } \\
\text { Petkova et al. 2011) }\end{array}$ & $\begin{array}{l}\text { - Lower exit opportunities for IPOs and } \\
\text { M\&As } \\
\text { - Lack of proven framework for evaluating } \\
\text { green ventures' potential } \\
\text { - Longer investment duration }\end{array}$ & $\begin{array}{l}\text { - Higher exit opportunities for IPOs and M\&As } \\
\text { - Existence of established frameworks for } \\
\text { evaluating ventures' potential (e.g. } \\
\text { biotechnology, software, aerospace) }\end{array}$ \\
\hline $\begin{array}{l}\text { Regulatory environment } \\
\text { (Bürer and Wüstenhagen 2009; Demirel } \\
\text { and Parris 2015; Wüstenhagen and } \\
\text { Teppo 2006) }\end{array}$ & $\begin{array}{l}\text { - Strictly regulated market with high } \\
\text { regulatory uncertainty }\end{array}$ & - Mixed regulated / laissez-faire markets \\
\hline $\begin{array}{l}\text { Market potential } \\
\text { (Bocken 2015; Klepper 2001; Petkova } \\
\quad \text { et al. 2014) }\end{array}$ & $\begin{array}{l}\text { - Legitimized emerging sectors appealing } \\
\text { for ideological, emotional or trend } \\
\text { reasons } \\
\text { - Better access to (green) niche-markets } \\
\text { and possibility of offering clearly dif- } \\
\text { ferentiated products } \\
\text { - Uncertain market environment due to } \\
\text { unstable prices of natural resources }\end{array}$ & $\begin{array}{l}\text { - Entrance in new submarkets, often dominated by } \\
\text { incumbents } \\
\text { - Service/product portfolio includes variants } \\
\text { of existing services/products }\end{array}$ \\
\hline
\end{tabular}

supersized returns (Cumming et al. 2013). Moreover, the combination of accelerated depletion of natural resources making the prices of the resources unstable (i.e., essentially increasing) and global warming making the environmental regulation progressively more stringent provides strong incentives to invest in green technologies. That is, market pull and policy push mechanisms for the green businesses are expected to strengthen by time. Finally, VC partners might find investing in green ventures more appealing even for ideological or emotional motives (Bocken 2015).

The above arguments lead us to posit that for high-tech ventures, the born-to-be-green signal may be positive, enabling them to an easier access to the VC market compared to the other high-tech ventures. Therefore, our first hypothesis is the following:

Hypothesis 1 (H1): Born-to-be-green is a positive signal for VCs and increases the likelihood to receive $\mathrm{VC}$, when compared to nongreen ventures.
However, there are plausible reasons to expect the opposite as well. Apart from the typical issues new highly-innovative ventures face to obtain external funding caused by the capital market imperfections (Carpenter and Petersen 2002)_, information asymmetry, highly variable returns, and intangible knowledgebased assets - there are peculiarities of green ventures, which might additionally hinder their odds of obtaining external funding, such as VC.

First, green technologies intrinsically entail extremely high technological complexity. Amore and Bennedsen (2016) show that green patents make citations to and receive citations from a wider range of technological classes, while the underlying environmental technologies also require more intensive R\&D spending. As a result, the complexity accentuates the causes of capital market imperfections. Second, as the green sector is in its infant stage, the managerial slack is inevitable, thus increasing the uncertainty of the new venture success. Both entrepreneurs and VCs - who should act as mentors 
to the former-lack relevant experience in the field, which causes the so-called "managerial valley of death" (Criscuolo and Menon 2015; Ghosh and Nanda 2010). Third, green ventures, even when successful, typically require longer time than nongreen ventures to become profitable, causing the extension of the investment duration, that exceeds the traditional time-to-return (approximately 710 years) VCs promise to their stakeholders (Knight 2010; Wüstenhagen and Teppo 2006). Additionally, new green ventures are typically highly capital intensive (Criscuolo and Menon 2015; Ghosh and Nanda 2010), which represents a barrier to a vast majority of VC firms, who are capital constrained for individual investments by the funds they manage (Cumming et al. 2013). Fourth, the green sector is different from the other high-tech sectors, such as biotech and ICT, in terms of exit opportunities for ventures. Green IPOs have historically been extremely rare (Petkova et al. 2011), while most of the large companies that could have potential for acquiring green ventures are focused on very different activities (e.g., fossil fuels) and have rarely engaged in acquisitions (Ghosh and Nanda 2010). Risky exit opportunities might create too high entry barriers for VCs (Wüstenhagen and Teppo 2006). Fifth, the success of new green ventures strongly depends on the governmental support, which introduces regulatory uncertainty in the investment equation for VC firms (Criscuolo and Menon 2015; Wüstenhagen and Teppo 2006). The profitability prospects of the ventures do not only depend on the underlying technological and market success, but also on the political behavior, which is inherently risky (Demirel and Parris 2015). Lastly, as in any other emerging sector, there is a lack of historical track-record for green VC investments, and a lack of proven frameworks for evaluating green ventures' potential (Petkova et al. 2014). Related to that, green products and processes mainly operate on the production side of the economy, such as electricity generation, energy efficiency, composite materials, wastewater treatment, where risks, returns, and market potential evaluations are more difficult (Cumming et al. 2013).

Relying on these arguments, we claim that born-to-be-green may also represent a negative signal toward $\mathrm{VC}$ investments, considering the higher risk, uncertainty, and complexity entailing the green businesses, compared to other high-tech ventures. Therefore, we posit the second competitive hypothesis:

Hypothesis 2 (H2): Born-to-be-green is a negative signal for $\mathrm{VCs}$ and decreases the likelihood to receive $\mathrm{VC}$, when compared to non-green ventures.

\section{Data and methodology}

\subsection{The RITA dataset}

We test our hypotheses on a sample of 361 Italian, independent, unlisted, and high-tech entrepreneurial firms that are less than 25 years old, founded between 1983 and 2008 and operate in the following industries: ICT manufacturing; biotechnology, pharmaceuticals, and advanced materials; aerospace, robotics, and process automation equipment; software; Internet and telecommunication services; environmental services; production of renewable energy; new materials and nanotechnologies; components and equipment for renewable energy; R\&D and engineering services.

Data are drawn from the RITA (Research on Entrepreneurship in Advanced Technologies) dataset (Colombo et al. 2009, 2014), which was firstly built by the largest technical Italian university at the end of 1999, and subsequently updated in 2002, 2004, 2007, and 2009. The survey-based part of the RITA dataset is based on questionnaires that were sent to a firm's contact person, i.e., a firm owner or a manager. The other part of the RITA dataset comes from secondary sources, such as (i) the Union of Italian Chambers of Commerce (Telemaco database) and (ii) the commercial databases CERVED and AIDA. For more details on the RITA dataset, see Appendix A.

\subsection{Model specification}

We use the following probit model specification:

$$
\begin{aligned}
\operatorname{Pr}(\mathrm{VC})= & \beta_{0}+\beta_{1} \text { Green }+\beta_{2} \text { FoundingTeam } \\
& +\beta_{3} \text { Patent }+\beta_{4} \text { University } \\
& +\beta_{5} \text { SubsBeforeVC }+\beta_{6} \text { Governance } \\
& +\beta_{7} \text { Controls }+\eta \mathrm{V}+\varepsilon_{\mathrm{i}}
\end{aligned}
$$


$\operatorname{Pr}(V C)$ is a dummy variable that equals one if the venture has been VC-backed after venture foundation. Green is a dummy variable that equals one if the venture is classified as green, according to the definition provided in Sect. 2. To identify green ventures, we manually checked each firm's website to assess whether its portfolio of (main) products/services/technologies can be classified as green. More specifically, we refer to the two definitions provided by the U.S. Bureau of Labor Statistics (source: http://www.bls.gov/green/\#definition) ${ }^{5}$ : (i) "businesses that produce goods or provide services that benefit the environment or conserve natural resources" or (ii) businesses that use "more environment-friendly production processes or use fewer natural resources" than their peers (for more details on such classification, see the Appendix B). The vector FoundingTeam includes the following variables at foundation: OpFounders is the logarithm of the number of active founders; OpFounders_Founders is the ratio between active founders and the total number of founders ${ }^{6}$; TechEducation is a dummy variable that equals one if at least one of the founders has obtained a bachelor degree in technical/scientific subjects; EcoEducation is a dummy variable that equals one if at least one of the founders has obtained a bachelor degree in economic/managerial subjects; SpecWorkExp is a dummy variable that equals one if at least one of the founders had work experience in the same industry of her/his venture before venture foundation; OtherWorkExp is a dummy variable that equals one if at least one of the founders had work experience in other industries than the one of her/his venture before venture foundation; FuctionalHeterogeneity is the Blau index calculated on three dummy variables that equal one if at least one of the founders had work experience in technical, productive, or commercial functions in the same industry of her/his venture before venture foundation, respectively; and SerialManager is a dummy variable that equals one if at least one of the founders had prior selfemployment experience or a management position in a company before venture foundation. Patent is a dummy variable that equals one if the venture has at least one patent at foundation. The vector University includes the following variables at foundation: Incubated is a dummy

\footnotetext{
${ }^{5}$ We started from the definition of green jobs and adapted it to venture's businesses.

${ }^{6}$ Similarly to Colombo et al. (2014), we define an active founder as a founder who was actively involved in venture management at foundation, while a non-active founder as a founder who only provided capital to her/his venture without having any managerial role.
}

variable that equals one if the venture was in an incubator or in a business innovation center; $A S U$ is a dummy variable that equals one if the venture is an academic spin-out. SubsBeforeVC is a dummy variable that equals one if the venture has been awarded with a public selective subsidy ${ }^{7}$ before having (eventually) received VC funding. The vector Governance includes the following variables at foundation: DebtFound is a dummy variable that equals one if the venture received debt capital; CorporateShareFound is a dummy that equals one if a part of venture's equity has held by a corporate shareholder. The vector Controls includes industry dummies; further, it accounts for time effects, which is measured by the foundation year, being every year potentially affected by different shocks influencing both the formation of green ventures and the likelihood to get VC. Finally, the vector $V$ includes unobserved variables that may impact both the venture likelihood to receive VC funding and the likelihood to be green (Angrist and Pischke 2008). Table 2 provides a brief overview of the variables included in eq. (1).

Detailed descriptive statistics of the above variables are shown in Table 3, while Table 4 reports the correlation matrix. In Appendix C, we report univariate Wald tests between green and non-green ventures to assess whether among the variables of interest any significant difference exists.

\subsection{Identification strategy}

To tackle the potential endogeneity in our model specification, we use several identification strategies. In fact, even though in eq. (1), we control for the most relevant potential signals the literature pinpoints as strong predictors of access to VC funding, we need to control for the self-selection bias in the process of getting VC. Such bias may potentially exist between green and non-green entrepreneurs, i.e., there may be systematic differences between these two categories of entrepreneurs in their propensity to actively search for $\mathrm{VC}$, in their type of search, and in their different perceptions about the chances to get VC. This way, as a first step to control for such endogeneity, we exploit venture-level information provided by the RITA dataset and directly related to

\footnotetext{
${ }^{7}$ We use the definition of selective subsidy suggested by Colombo et al. (2011, p. 97): “A selective scheme provides financial support to selected applicants. In this case, applicants compete for receiving a subsidy and their projects are judged by committees formed by experts who are appointed by the government".
} 
Table 2 Definition of explanatory variables

\begin{tabular}{ll}
\hline Variable & Definition \\
\hline Green & $\begin{array}{c}\text { Dummy that equals one if the venture is } \\
\text { green }\end{array}$
\end{tabular}

Founding team variables

OpFounders

Logarithm of the number of active founders

OpFounders_Founders Ratio between active founders and the total number of founders

TechEducation

Dummy that equals one if at least one of the founders has obtained a bachelor degree in technical/scientific subjects

EcoEducation

Dummy that equals one if at least one of the founders has obtained a bachelor degree in economic/managerial subjects

SpecWorkExp

OtherWorkExp

Dummy that equals one if at least one of the founders had work experience in the same industry of her/his venture before venture foundation

Dummy that equals one if at least one of the founders had work experience in other industries than the one of her/his venture before venture foundation

FuctionalHeterogeneity Blau index calculated on three dummy variables that equal one if at least one of the founders had work experience in technical, productive, or commercial functions in the same industry of her/his venture before venture foundation, respectively

SerialManager

Dummy that equals one if at least one of the founders had prior selfemployment experience or a management position in a company before venture foundation

Patent

University variables

Incubated

ASU

SubsBeforeVC

\section{Governance variables}

DebtFound

Dummy that equals one if the venture received debt capital at foundation

CorporateShareFound Dummy that equals one if a part of venture's equity has held by a corporate shareholder at foundation
Table 2 (continued)

\begin{tabular}{ll}
\hline Variable & Definition \\
\hline Controls & \\
$\begin{array}{l}\text { FoundYear } \\
\text { Manufacturing }\end{array}$ & $\begin{array}{r}\text { Venture's foundation year } \\
\text { Dummy that equals one if the venture } \\
\text { operates in a manufacturing industry }\end{array}$ \\
\hline
\end{tabular}

the "active search for VC financing" and include such information to preliminary isolate the possible endogeneity effect. In other words, we know which firms actively searched for VC (and those that did not), and we exploit this information by including such venture-specific "searching for VC" term as an additional regressor in eq. (1)..$^{8}$

In addition, we use a linear IV procedure, ${ }^{9}$ which represents a more solid empirical approach. As exclusion restriction, we use a variable sourced from the World Values Survey (WVS) ${ }^{10}$ and related to the awareness about environmental issues of the local community where the focal venture is located. Specifically, our region-level variable is Income for Environment. This refers to the following survey question: "I am going to read out some statements about the environment. For each one, can you tell me whether you strongly agree, agree, disagree or strongly disagree?". We consider survey respondents who express their agreement on the sub-item "I would give part of my income if I were certain that the money would be used to prevent environmental pollution" on a 1-4 scale where 1 means "strongly agree" and 4 means "strongly disagree." Income for Environment is a dummy variable that equals one if the answer to the above sub-item is 1 "strongly

\footnotetext{
${ }^{8}$ A Heckman-type approach could be suitable in our setting. However, the use of a Heckman-type approach implies to keep in the main equation only the ventures that actively searched VC. Therefore, this approach may prevent us to understand another shade of the phenomenon, and could potentially reduce the generalizability of our findings. In some cases, in fact, VCs directly contact entrepreneurs in several ways (e.g. participating at start-up competitions) (Samila and Sorenson 2011). We are grateful to an anonymous reviewer for this suggestion.

${ }^{9}$ We avoid IV probit estimates because Wooldridge (2010) has shown how such estimates are dramatically biased by potential heteroskedasticity.

${ }^{10}$ WVS data are about human values, motivations and beliefs, and are collected through nationally representative surveys on around the $90 \%$ of the world's population. For more details see: http://www. worldvaluessurvey.org/wvs.jsp. For other works using WVS data see e.g. Benabou et al. (2015) and Deaton (2008). For empirical works on green and/or environmental issues see e.g. Brechin (1999) and Dunlap and Mertig (1997).
} 
Table 3 Descriptive statistics

\begin{tabular}{|c|c|c|c|c|c|c|}
\hline & Obs. & Mean & Median & Min. & Max. & Std. Dev. \\
\hline $\operatorname{Pr}(\mathrm{VC})$ & 361 & 0.0776 & 0 & 0 & 1 & 0.2679 \\
\hline Green & 361 & 0.1717 & 0 & 0 & 1 & 0.3777 \\
\hline OpFounders & 361 & 1.2269 & 1.0986 & 0.6931 & 2.3979 & 0.3498 \\
\hline OpFounders_Founders & 361 & 0.8755 & 1 & 0.0476 & 1 & 0.2250 \\
\hline TechEducation & 361 & 0.5235 & 1 & 0 & 1 & 0.5001 \\
\hline EcoEducation & 361 & 0.1330 & 0 & 0 & 1 & 0.3400 \\
\hline SpecWorkExp & 361 & 0.4349 & 0 & 0 & 1 & 0.4964 \\
\hline OtherWorkExp & 361 & 0.6870 & 1 & 0 & 1 & 0.4644 \\
\hline FuctionalHeterogeneity & 361 & 0.3283 & 0.25 & 0 & 1 & 0.1601 \\
\hline SerialManager & 361 & 0.4543 & 0 & 0 & 1 & 0.4986 \\
\hline Patent & 361 & 0.0803 & 0 & 0 & 1 & 0.2722 \\
\hline Incubated & 361 & 0.1884 & 0 & 0 & 1 & 0.3915 \\
\hline ASU & 361 & 0.1856 & 0 & 0 & 1 & 0.3893 \\
\hline SubsBeforeVC & 361 & 0.0665 & 0 & 0 & 1 & 0.2495 \\
\hline DebtFound & 361 & 0.1136 & 0 & 0 & 1 & 0.3177 \\
\hline CorporateShareFound & 361 & 0.0471 & 0 & 0 & 1 & 0.2121 \\
\hline FoundYear & 361 & 1998 & 1999 & 1983 & 2008 & 6.6586 \\
\hline Manufacturing & 361 & 0.4903 & 0 & 0 & 1 & 0.5006 \\
\hline
\end{tabular}

agree." As highlighted by Florin et al. (2003), local social capital and values of the community shape the resources of the venture and its access to the social resources embedded in the community (see also Seibert et al. 2001). In particular, venture characteristics relate to the nature of the resources embedded in the community. Venture founders may access information and assimilate knowledge and values from their community (Cohen and Levinthal 1990). Informationally rich social communities also enhance the venture's ability to withstand random environmental shocks (Bruderl et al. 1992; Cooper et al. 1994), especially if such communities share strong environmentally related values. In this respect, we claim that the Italian regions, where the shared environmentally related values are more developed and the green awareness of the community is stronger, are the regions where entrepreneurs are more likely to start-up green businesses. First, entrepreneurs expect stronger acceptance and help by their community in those regions. Second, entrepreneurs are more likely to assimilate and absorb green values in those regions and translate them into business ideas and ventures. To this latter extent, Peterson and Roquebert (1993) show how community values influence entrepreneurial beliefs about the viability of the potential venture and shape the motivations to startup a business venture and its related characteristics.

While the above arguments speak in favor of a positive correlation between community-level green values and the presence of local green ventures, there is no reason to claim a positive association between community-level green values and the presence of VCs in the local area for several reasons. First, VC funds usually invest with the primary aim to get the highest capital return in the shortest possible time horizon (Gompers and Lerner 2001). Then, they target potentially cash-generating ventures regardless their geographical location, i.e., Italian VC funds invest across regions (Martin et al. 2002) and a few of them also engage in cross-border investments (Schertler and Tykvová 2012). Second, to the best of our knowledge, while there is strong empirical evidence that VC funds target and strategically design their investments through syndication networks, so exploiting VC community resources (Sorenson and Stuart 2001), there is no empirical evidence that VC investments are driven by community values. As expected, the correlation between Income for Environment and our dependent variable 


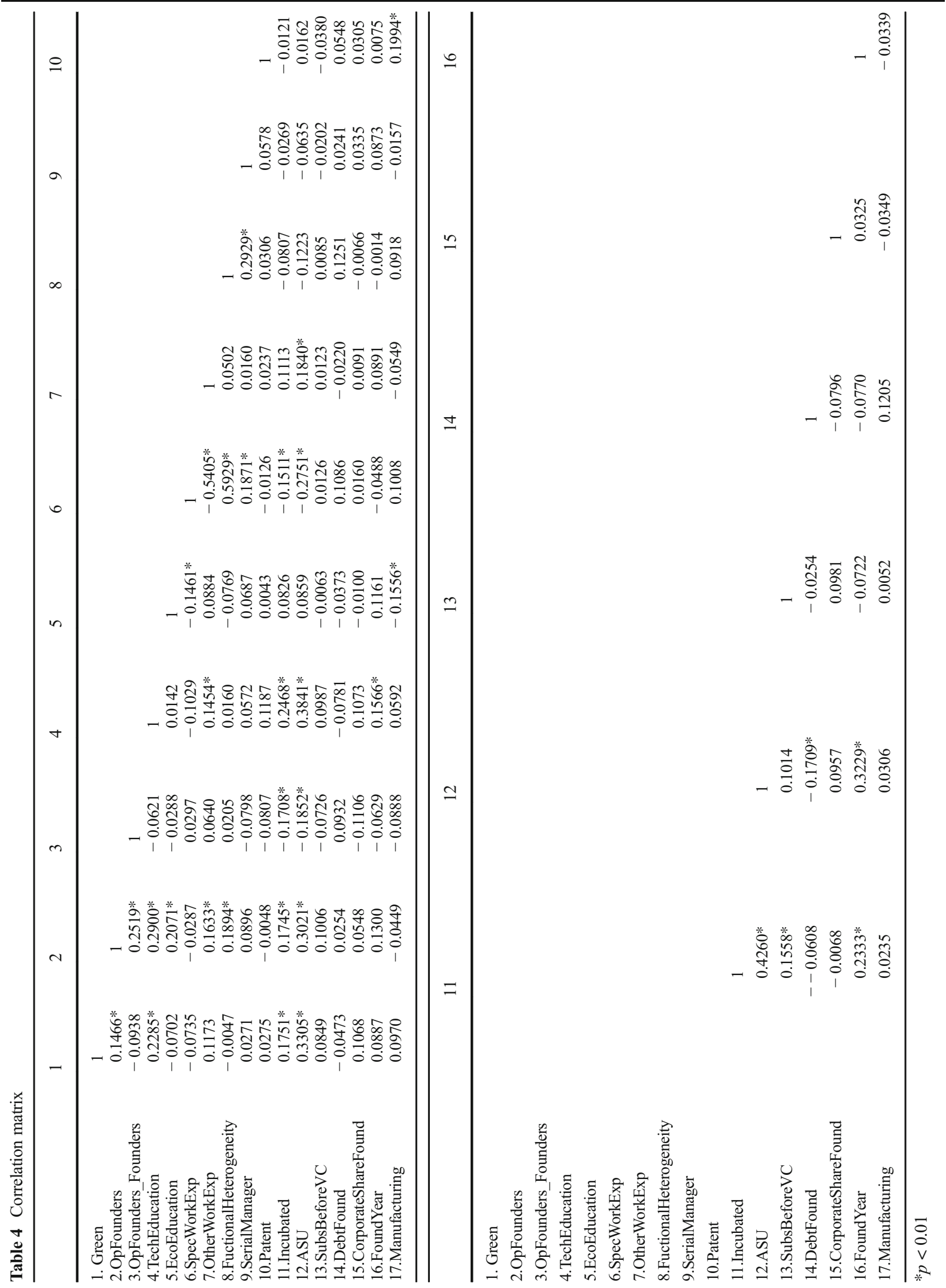


$\operatorname{Pr}(V C)$ is not statistically significant and its magnitude is quite low $(-3.1 \%){ }^{11}$

Lastly — and related to our specific setting — our analysis is at company-level while the instrument is at region-level. This way, we can safely eliminate any concerns about reverse causality (Acemoglu et al. 2005) - and this is especially important in crosssectional studies. Moreover, all regressors are at foundation or before the eventual VC-backing. However, in our cross-section analysis, we cannot exclude that endogeneity concerns related to sequential exogeneity are at work. Thus, in line with Ayyagari et al. (2011) and Chen et al. (2011), we let this identification issue to future research.

\section{Results}

Table 5 shows the results of our baseline model specifications. In the first two columns, we estimate eq. (1) by means of probit regressions (in the second column, we control for the entrepreneurial active search for $\mathrm{VC}$ ). We find a positive and statistically significant (at $1 \%$ confidence level) impact of TechEducation on the likelihood to get VC: the marginal effect ranges between +3.52 (significant at $5 \%$ ) and +4.76 (significant at $1 \%$ ). As to SpecWorkExp, we find a statistically significant (at 5\%) negative effect on VC-backing: marginal effects range between -3.39 and $-5.45 \%$ - both significant at $5 \%$ confidence level. FuctionalHeterogeneity leads to a positive and statistically significant (at 5\%) contribution to the likelihood to access VC: the marginal effect at means is estimated to range between +9.47 and $+18.83 \%$. Quite surprisingly, we find that the presence in venture teams of previously self-employed founders or founders with a prior management experience shrinks the likelihood to get VC: marginal effects range from $-2.16 \%$ in column II (significant at $1 \%$ ) to $-3.14 \%$ in column I (significant at $5 \%$ ). This finding may be explained by the fact that serial entrepreneurs and entrepreneurs with prior executive experience are usually more connected to complementary asset providers (Westhead et al. 2005). This way, such connections may lead to more external (e.g., banks) and internal (e.g., cash) sources to

\footnotetext{
$\overline{11}$ As robustness check, we use an alternative exclusion restriction: the cross-region variation in laws implemented by local governments to foster green innovations over time. Results are fully in line with the main ones in Table 5 and are shown in Table D1. For more details about these additional estimates see Appendix D.
}

finance venture operations, making VC less appealing. While in Table 5 (columns I and II), the coefficient of the variable $A S U$ is positive and statistically significant (at 10 and 5\%, respectively), when controlling for the entrepreneurial search for VC (column II), the marginal effect is not statistically significant. As to the presence of corporate shareholders at foundation, it increases the likelihood to get VC: the estimated marginal effects range between +20.17 and $+24.98 \%$, both significant at $1 \%$. Regarding our main independent variable, our estimates show that running a green business per se is not correlated with the likelihood to receive $\mathrm{VC}$, and its marginal effect is not statistically significant.

When moving to IV estimates (column III), we find the same results described above, except for the following ones: TechEducation has still a positive coefficient, but it loses some statistical significance (from $1 \%$ to 10\% level); SpecWorkExp, FuctionalHeterogeneity, and SerialManager have still the same sign but they lose statistical significance; and the coefficient of $A S U$ is now statistically correlated at $1 \%$ level with the likelihood to become VC-backed. These results may be expected because of the better control for unobserved heterogeneity by means of our IV design. It is worth noting that the F-statistic of the first stage of our IV system of equations reassures the reader about the goodness of our exclusion restriction.

In Table 6, we exploit venture-level information included in the RITA dataset, which enables us to identify the ventures positioning their business in a green sector, ${ }^{12}$ and those that did not, using the self-declared sectoral classification. Thus, we run our baseline models substituting the variable Green with the dummy variable GreenSelf that equals one if the venture self-declared to operate in a green sector, while it takes the value zero otherwise. The introduction of this further categorization enables us to distinguish between ventures using truly green technologies or offering green products/ services regardless of the sector of activity (horizontal view across sectors) and ventures positioning their business specifically in a green sector (vertical view within a single sector). We measure the former by employing the variable Green, while the latter is based on self-reported information on the industrial sector of activity, i.e., the

\footnotetext{
${ }^{12}$ In the RITA dataset the following sectors fall into the "green" category: environmental services, production of renewable energy, new materials and nanotechnologies, components and equipment for renewable energy.
} 
Table 5 Baseline econometric results

\begin{tabular}{|c|c|c|c|}
\hline & $\begin{array}{l}\text { Model (1) } \\
\text { Probit }\end{array}$ & $\begin{array}{l}\text { Model (2) } \\
\text { Probit }\end{array}$ & $\begin{array}{l}\text { Model (3) } \\
\text { IV }\end{array}$ \\
\hline Green & $\begin{array}{c}0.3519 \\
(0.2843)\end{array}$ & $\begin{array}{c}0.3991 \\
(0.2605)\end{array}$ & $\begin{array}{r}-0.5017 \\
(0.3915)\end{array}$ \\
\hline OpFounders & $\begin{array}{c}0.2841 \\
(0.3793)\end{array}$ & $\begin{array}{c}0.5696 \\
(0.4144)\end{array}$ & $\begin{array}{c}0.0617 \\
(0.0758)\end{array}$ \\
\hline OpFounders_Founders & $\begin{array}{c}-0.1563 \\
(0.3004)\end{array}$ & $\begin{array}{c}0.1216 \\
(0.3762)\end{array}$ & $\begin{array}{c}-0.0374 \\
(0.0603)\end{array}$ \\
\hline TechEducation & $\begin{array}{c}0.5990 * * * \\
(0.2072)\end{array}$ & $\begin{array}{c}0.7761 * * * \\
(0.2007)\end{array}$ & $\begin{array}{l}0.0823 * \\
(0.0450)\end{array}$ \\
\hline EcoEducation & $\begin{array}{c}0.2291 \\
(0.2552)\end{array}$ & $\begin{array}{c}-0.0065 \\
(0.2813)\end{array}$ & $\begin{array}{c}-0.0398 \\
(0.0644)\end{array}$ \\
\hline SpecWorkExp & $\begin{array}{c}-0.7168^{* *} \\
(0.3170)\end{array}$ & $\begin{array}{c}-0.7942 * * \\
(0.3257)\end{array}$ & $\begin{array}{c}-0.0531 \\
(0.0491)\end{array}$ \\
\hline OtherWorkExp & $\begin{array}{c}-0.1953 \\
(0.2653)\end{array}$ & $\begin{array}{c}-0.0245 \\
(0.2585)\end{array}$ & $\begin{array}{c}0.0078 \\
(0.0453)\end{array}$ \\
\hline FuctionalHeterogeneity & $\begin{array}{c}2.3895 * * \\
(1.0646)\end{array}$ & $\begin{array}{c}2.1744 * * \\
(1.1011)\end{array}$ & $\begin{array}{c}0.1923 \\
(0.1419)\end{array}$ \\
\hline SerialManager & $\begin{array}{c}-0.4061^{* * *} \\
(0.1986)\end{array}$ & $\begin{array}{c}-0.5023 * * \\
(0.2399)\end{array}$ & $\begin{array}{c}-0.0192 \\
(0.0273)\end{array}$ \\
\hline Patent & $\begin{array}{c}0.3377 \\
(0.3186)\end{array}$ & $\begin{array}{c}0.3412 \\
(0.2912)\end{array}$ & $\begin{array}{c}0.0317 \\
(0.0688)\end{array}$ \\
\hline Incubated & $\begin{array}{c}0.0143 \\
(0.1460)\end{array}$ & $\begin{array}{r}-0.2511 \\
(0.1942)\end{array}$ & $\begin{array}{c}0.0221 \\
(0.0507)\end{array}$ \\
\hline ASU & $\begin{array}{l}0.3199 * \\
(0.1905)\end{array}$ & $\begin{array}{c}0.5759 * * \\
(0.2365)\end{array}$ & $\begin{array}{c}0.2324 * * * \\
(0.0892)\end{array}$ \\
\hline SubsBeforeVC & $\begin{array}{c}0.3732 \\
(0.4400)\end{array}$ & $\begin{array}{c}0.4307 \\
(0.4620)\end{array}$ & $\begin{array}{c}0.0603 \\
(0.1013)\end{array}$ \\
\hline DebtFound & $\begin{array}{c}0.0582 \\
(0.3211)\end{array}$ & $\begin{array}{c}0.3562 \\
(0.3141)\end{array}$ & $\begin{array}{c}0.0082 \\
(0.0426)\end{array}$ \\
\hline CorporateShareFound & $\begin{array}{c}1.2820 * * * \\
(0.2655)\end{array}$ & $\begin{array}{c}1.3882 * * * \\
(0.2974)\end{array}$ & $\begin{array}{c}0.3746 * * * \\
(0.1398)\end{array}$ \\
\hline FoundYear & $\begin{array}{c}0.0185 \\
(0.0114)\end{array}$ & $\begin{array}{c}0.0151 \\
(0.0147)\end{array}$ & $\begin{array}{c}0.0006 \\
(0.0024)\end{array}$ \\
\hline Manufacturing & $\begin{array}{c}0.1316 \\
(0.1738)\end{array}$ & $\begin{array}{c}0.1234 \\
(0.2126)\end{array}$ & $\begin{array}{c}0.0487 \\
(0.0402)\end{array}$ \\
\hline FinancingSearch & & $\begin{array}{c}1.2690^{* * *} \\
(0.2054)\end{array}$ & \\
\hline $\begin{array}{l}\text { Number of } \\
\text { observations } \\
\text { Pseudo } \mathrm{R}^{2}\end{array}$ & 361 & $\begin{array}{c}352 \\
0.3549\end{array}$ & 361 \\
\hline Centered $\mathrm{R}^{2}$ & & & 0.3727 \\
\hline F-statistic first stage & & & $476.13 * * *$ \\
\hline
\end{tabular}

$* p<0.10, * * p<0.05, * * * p<0.01$. The dependent variable is the likelihood to get VC. Estimates are derived from probit (columns I and II) and linear IV regressions with region-clustered standard errors. All regressions are estimated with an intercept term. Standard errors in round brackets variable GreenSelf. As shown in Table 6, business activity in a self-reported green sector is strongly and positively correlated with the likelihood to get VC: the estimated marginal effect ranges between $+5.52 \%$ (significant at $5 \%$ ) and $+8.06 \%$ (significant at $1 \%$ ). As to the other findings, they are fully in line with those shown in Table 5.

In this model specification, we do not use an IV design because our exclusion restriction cannot predict entrepreneurs' perceptions about their business.

However, in Table 6, we are not able to assess the effect of the born-to-be-green signal stemming from ventures deploying green technologies (or offering green products/services) and positioning themselves in a green sector, at the same time. To this extent, in Table 7, we substitute the variable Green-included in eq. (1) - with three dummy variables: GreenSelf_Green, GreenSelf_NoGreen, and NoGreenSelf_Green. GreenSelf_Green equals one if the venture selfdeclared to operate in a green sector and the dummy variable Green equals one; GreenSelf_NoGreen equals one if the venture self-declared to operate in a green sector and the dummy variable Green equals zero; and NoGreenSelf_Green equals one if the venture selfdeclared to not operate in a green sector but the dummy variable Green equals one. This way, we are able to investigate three scenarios associated to two dimensions of the born-to-be-green signal, i.e., the adoption of a green technology (or the offer of a green product/service), and the entrepreneurial ability to position the venture into a green sector. In particular, we analyze three situations: (i) entrepreneurs who run a green business and position it in a green sector, (ii) entrepreneurs who run a non-green business but position it in a green sector, and (iii) entrepreneurs who run green businesses but do not position it in a green sector.

As shown in Table 7, only entrepreneurs included in the first category, i.e., who run a green business and position it into a green sector, are more likely to access VC markets: the estimated marginal effect is $+7.08 \%$ (significant at 5\%). As to the other findings, they are still fully in line with those shown in Tables 5 and 6.

Finally, we dig into the data to investigate three contingencies that may moderate the association between green business propositions and the likelihood to get VC: the technical/scientific education of the founder(s), the origin of the firm as academic spin-out, and the presence of corporate shareholders into the venture' $s$ equity. We find that while technical/scientific education 
Table 6 Econometric results controlling for self-positioning into a green sector

\begin{tabular}{|c|c|c|}
\hline & Model (1) & Model (2) \\
\hline GreenSelf & $\begin{array}{c}0.6480 * * * \\
(0.1794)\end{array}$ & $\begin{array}{c}0.7061 * * * \\
(0.2028)\end{array}$ \\
\hline OpFounders & $\begin{array}{c}0.2932 \\
(0.3963)\end{array}$ & $\begin{array}{c}0.5802 \\
(0.4379)\end{array}$ \\
\hline OpFounders_Founders & $\begin{array}{c}-0.1372 \\
(0.3175)\end{array}$ & $\begin{array}{c}0.1693 \\
(0.4124)\end{array}$ \\
\hline TechEducation & $\begin{array}{c}0.6006 * * * \\
(0.2038)\end{array}$ & $\begin{array}{c}0.7932 * * * \\
(0.2019)\end{array}$ \\
\hline EcoEducation & $\begin{array}{c}0.2066 \\
(0.2539)\end{array}$ & $\begin{array}{c}-0.0330 \\
(0.2840)\end{array}$ \\
\hline SpecWorkExp & $\begin{array}{c}-0.7816^{* * *} \\
(0.3494)\end{array}$ & $\begin{array}{c}-0.8927 * * \\
(0.3621)\end{array}$ \\
\hline OtherWorkExp & $\begin{array}{c}-0.1584 \\
(0.2548)\end{array}$ & $\begin{array}{l}-0.0040 \\
(0.2412)\end{array}$ \\
\hline FuctionalHeterogeneity & $\begin{array}{c}2.4357 * * \\
(1.1329)\end{array}$ & $\begin{array}{l}2.2993 * \\
(1.1913)\end{array}$ \\
\hline SerialManager & $\begin{array}{c}-0.4236^{*} \\
(0.2198)\end{array}$ & $\begin{array}{c}-0.5280^{* *} \\
(0.2650)\end{array}$ \\
\hline Patent & $\begin{array}{c}0.3485 \\
(0.3108)\end{array}$ & $\begin{array}{c}0.3539 \\
(0.2809)\end{array}$ \\
\hline Incubated & $\begin{array}{c}-0.0910 \\
(0.1379)\end{array}$ & $\begin{array}{c}-0.3594 * * \\
(0.1718)\end{array}$ \\
\hline ASU & $\begin{array}{c}0.3880 * * \\
(0.1719)\end{array}$ & $\begin{array}{c}0.6433 \text { *** } \\
(0.2183)\end{array}$ \\
\hline SubsBeforeVC & $\begin{array}{c}0.3907 \\
(0.4422)\end{array}$ & $\begin{array}{c}0.4324 \\
(0.4487)\end{array}$ \\
\hline DebtFound & $\begin{array}{c}0.0797 \\
(0.3105)\end{array}$ & $\begin{array}{c}0.3828 \\
(0.3146)\end{array}$ \\
\hline CorporateShareFound & $\begin{array}{c}1.3449 * * * \\
(0.2836)\end{array}$ & $\begin{array}{c}1.4988 * * * \\
(0.3323)\end{array}$ \\
\hline FoundYear & $\begin{array}{c}0.0182 \\
(0.0119)\end{array}$ & $\begin{array}{c}0.0145 \\
(0.0154)\end{array}$ \\
\hline Manufacturing & $\begin{array}{c}0.1668 \\
(0.1824)\end{array}$ & $\begin{array}{c}0.1602 \\
(0.2168)\end{array}$ \\
\hline FinancingSearch & & $\begin{array}{c}1.2731 * * * \\
(0.2035)\end{array}$ \\
\hline Number of observations & 361 & 352 \\
\hline Pseudo $R^{2}$ & 0.2658 & 0.3626 \\
\hline
\end{tabular}

$* p<0.10, * * p<0.05, * * * p<0.01$. The dependent variable is the likelihood to get VC. Estimates are derived from probit regressions with region-clustered standard errors. All regressions are estimated with an intercept term. Standard errors in round brackets
Table 7 Econometric results matching green classification with self-positioning into a green sector

\begin{tabular}{|c|c|}
\hline & Model (1) \\
\hline GreenSelf_Green & $\begin{array}{c}0.8193 * * * \\
(0.2584)\end{array}$ \\
\hline GreenSelf_NoGreen & $\begin{array}{c}0.4657 \\
(0.9359)\end{array}$ \\
\hline NoGreenSelf_Green & $\begin{array}{c}0.1915 \\
(0.3107)\end{array}$ \\
\hline OpFounders & $\begin{array}{c}0.5708 \\
(0.4391)\end{array}$ \\
\hline OpFounders_Founders & $\begin{array}{c}0.1474 \\
(0.4079)\end{array}$ \\
\hline TechEducation & $\begin{array}{c}0.8037 * * * \\
(0.1753)\end{array}$ \\
\hline EcoEducation & $\begin{array}{r}-0.0020 \\
(0.2914)\end{array}$ \\
\hline SpecWorkExp & $\begin{array}{r}-0.8805 * * \\
(0.3285)\end{array}$ \\
\hline OtherWorkExp & $\begin{array}{c}-0.0159 \\
(0.2517)\end{array}$ \\
\hline FuctionalHeterogeneity & $\begin{array}{c}2.3038^{* *} \\
(1.1218)\end{array}$ \\
\hline SerialManager & $\begin{array}{c}-0.5404 * * \\
(0.2624)\end{array}$ \\
\hline Patent & $\begin{array}{c}0.3564 \\
(0.2832)\end{array}$ \\
\hline Incubated & $\begin{array}{c}-0.3493 * \\
(0.1841)\end{array}$ \\
\hline ASU & $\begin{array}{c}0.5971 * * \\
(0.2407)\end{array}$ \\
\hline SubsBeforeVC & $\begin{array}{c}0.4204 \\
(0.4626)\end{array}$ \\
\hline DebtFound & $\begin{array}{c}0.3873 \\
(0.3126)\end{array}$ \\
\hline CorporateShareFound & $\begin{array}{c}1.4661 * * * \\
(0.3077)\end{array}$ \\
\hline FoundYear & $\begin{array}{c}0.0142 \\
(0.0150)\end{array}$ \\
\hline Manufacturing & $\begin{array}{c}0.1646 \\
(0.2166)\end{array}$ \\
\hline FinancingSearch & $\begin{array}{c}1.2904 * * * \\
(0.1709)\end{array}$ \\
\hline Number of observations & 352 \\
\hline Pseudo $\mathrm{R}^{2}$ & 0.3648 \\
\hline
\end{tabular}

$* p<0.10, * * p<0.05, * * * p<0.01$. The dependent variable is the likelihood to get VC. Estimates are derived from probit regressions with region-clustered standard errors. All regressions are estimated with an intercept term. Standard errors in round brackets 
of the founder(s) has a negative moderating effect, being an academic spin-out and having corporate shareholders positively moderates the likelihood for a venture to get VC. For a detailed description of the procedure and results, see Appendix E.

\section{Discussion and conclusions}

The aim of this paper was to understand whether bornto-be-green acts as signal toward VC investments. Our results showed that born-to-be-green does not influence per se the likelihood to receive VC. In other words, other things being equal, ventures that perform green-based activities and use green technologies are not more likely to access the VC market, compared to other high-tech ventures. Such negligible effect of the green signal per se is in line with our theoretical arguments, which suggest the presence of competing effects at work.

Therefore, we deepen the complex phenomenon of the born-to-be-green signal by distinguishing the two different sources of such signal, offering a twodimensional categorization of high-tech green ventures. In order to classify them, we make a clear distinction between ventures using truly green technologies or offering green products/services regardless of the sector of activity (horizontal view across sectors) - i.e., green signal per se - and ventures positioning their business specifically in a green sector (vertical view within a single sector). This twofold view, both horizontal and vertical, enables us to better distinguish the signaling effect that may stem, on the one hand, from the adoption of a green technology (or the offer of a green product/ service) and, on the other hand, from the entrepreneurial ability to position the venture within a green sector.

We found that a reliable signal for investors will stem only from truly deploying green technologies (or offering green products/services) and positioning the venture accordingly in a green sector, at the same time. Indeed, re-adapting the idea of Heil and Robertson (1991) that "a new product signal will create more perceived sender commitment if the sender has potentially available production capacity" (p. 408), we argue that the alignment between the core green business and the ability of the entrepreneur to position her/his venture within such business makes the "sender of the green signal" more committed to the eyes of potential VC investors.

We interpret our results to be a consequence of the importance of signals for high-tech entrepreneurial ventures, but most importantly to be the outcome of the crucial role that entrepreneurs have in sending reliable signals to the external financial market (Connelly et al. 2011). In order to be effective, the born-to-begreen signal needs to be properly communicated by the entrepreneurial ability to position the business and also needs to be aligned with the actual venture's underlying technology/product portfolio.

This work contributes to the literature on green entrepreneurship by empirically testing differences between green and non-green high-tech ventures to access the VC market. We first provide theoretical arguments to highlight differential characteristics existing between green ventures and "average" high-tech non-green ventures that may also affect their attractiveness to $\mathrm{VC}$ investors. Further, the empirical results add to the related works about competitiveness of new green ventures (Meyskens and Carsrud 2013; Parrish 2010). We complement the work of Meyskens and Carsrud (2013), who state that partners bring the necessary resources to the early stage green ventures that help them succeed. This work provides also original contributions to the literature on VC and signals. Following Petkova et al. (2014), we offer new evidence on $\mathrm{VC}$ reactions in emerging sectors. Moreover, our study complements the literature on signals, introducing new evidence on the born-to-begreen effect.

Some limitations of the present study are worth noting, as they can also open up new promising directions for future research. First, the question regarding the effectiveness of the born-to-be-green signal to access the VC market should be studied in a cross-country setting. It would be interesting to see how different degrees of development of the VC market, the heterogeneity of green-oriented laws promoted by the local and central governments, and country-level cultural traits may differently affect the results provided by the present study. Second, following the studies of Demirel and Kesidou (2011), Demirel and Parris (2015), and Kesidou and Demirel (2012), it would be of great interest to deeper analyze the role of environmental regulations and types of eco-innovations as moderating factors of the relationship between the born-to-be-green signal and the likelihood to attract VC investments. Third, even if we elaborated on the market pull and policy push mechanisms (i.e., demand) as theoretical supporting arguments in favor of the possible positive signal of born-to-be-green for VC investors, we should acknowledge that the demand for green businesses' 
products and processes is largely exogenous. ${ }^{13}$ As such, future studies should deepen the demand structures of such products and processes to better understand how this affect the expected return from VC investments. Finally, in this study, we categorized green businesses mainly using the venture's perspective, by relying on objective criteria (regarding their activities and technologies they use), and on self-reported information by the entrepreneur (about sector of activity). Future works may also take into consideration the VCs' perspective and study how they interpret and perceive the green signal and how they identify a green venture.

Acknowledgements The authors are grateful to the Special Issue Editors Pelin Demirel, Francesco Rentocchini and Jagannadha Pawan Tamvada, and two anonymous reviewers. The current version of this study has benefited from comments offered by Yan Alperovich, Giuliana Battisti, Marco Vivarelli, and Tom Vanacker, as well as by the participants of the 2015 workshop "Born To Be Green: the Economics and Management of Green Start-Ups" (Winchester, the UK) and the ENTFIN Conference 2016 (Lyon, France). Responsibility for any errors lies solely with the authors. The authors equally contributed to this work.

\section{Appendix A: Description of the RITA dataset}

The sample used for testing out hypotheses was drawn from the RITA dataset. The sample includes 361 Italian, independent, unlisted, and high-tech entrepreneurial firms that are less than 25 years old, founded between 1983 and 2008 and operating in the following industries: ICT manufacturing (i.e., computers; electronic components; telecommunication equipment; optical, medical, and electronic instruments); biotechnology, pharmaceuticals, and advanced materials; aerospace, robotics and process automation equipment; software; Internet and telecommunication services; environmental services; production of renewable energy; new materials and nanotechnologies; components and equipment for renewable energy; R\&D and engineering services. The associated NACE rev. 1.1 codes are the following: ICT manufacturing (30.02, 32, 33); biotechnology (73.1); pharmaceuticals and advanced materials (24.4); aerospace, robotics, and process automation (29.5, 35.5); software (72.2); Internet and telecommunications services $(64.2,72.60)$. The other industries are not explicitly included in the NACE rev. 1.1 classification.

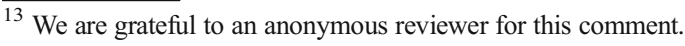

The RITA (Research on Entrepreneurship in Advanced Technologies) dataset was firstly built by the largest technical Italian university at the end of 1999, and subsequently updated in 2002, 2004, 2007, and 2009. Information in the RITA dataset are collected from two types of sources. First, the survey-based part of the RITA dataset is based on questionnaires that were sent to a firm's contact person, i.e., a firm owner or a manager. The reliability of the answers to the questionnaires was checked by trained research assistants and cross-checked with firms' annual reports and publicly available information. If necessary, follow-up interviews were conducted. Second, the other part of the RITA dataset comes from secondary sources, such as the following: (i) the Union of Italian Chambers of Commerce (Telemaco database) to check the official status of the firms and control for firm exit (i.e., bankruptcy or merger/acquisition) and potential survivorship bias $^{14}$ and (ii) the commercial databases CERVED and AIDA (the Italian version of Bureau van Dijk's Orbis) for the inclusion of accounting data. For more details on the RITA dataset, see Colombo et al. (2009, 2014).

\section{Appendix B: Classification of green and non-green businesses}

In order to classify the business in our sample with respect to the green business activities, we used a comprehensive and well-established definition and drew from it to manually checked each venture's website to assess whether their portfolio of products, services, and/ or technologies can be classified as green. In particular, we drew from the U.S. Bureau of Labor Statistics's (BLS's) definition of green. ${ }^{15}$ The BLS definition provides a clear, measurable, and complete description of green activities, which facilitates a straightforward and unambiguous classification (e.g., BLS uses it for a

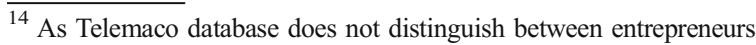
from workers with atypical employment contracts, a careful activity of data cleaning was undertaken to exclude the latter ones. Further, all the local offices and the ventures coming from changes in the legal form of already existing companies were dropped. These data-related activities were done when the RITA database was assembled. The legal statuses of sampled firms are: sole proprietorships and partnerships (around $40 \%$ of the sample) and limited companies (around $60 \%$ of the sample). As regards company size, $10 \%$ of the sampled firms have no employees at foundation date, the median (mean) number of employees at foundation date is 3 (4).

${ }^{15}$ For a detailed definition and related information, please see the devoted page on the official webpage of the U.S. Bureau of Labor Statistics (http://www.bls.gov/green/).
} 
Table 8 Typology and description of green business activities defined by the U.S. Bureau of Labor Statistics

General type of green business Detailed groups of green activities business activities

i. Business activities that produce goods or provide services that benefit the environment or conserve natural resources.

1. Energy from renewable sources. Electricity, heat, or fuel generated from renewable sources (e.g. wind, biomass, geothermal, solar, ocean, hydropower, landfill gas and municipal solid waste, etc.).

2. Energy efficiency. Products and services that improve energy efficiency (e.g. energy-efficient equipment, appliances, buildings, vehicles, energy storage and distribution, etc.).

3. Pollution reduction and removal, greenhouse gas reduction, and recycling and reuse. These are products and services that:

- Reduce or eliminate creation or release of pollutants or toxic compounds, or remove pollutants or hazardous waste from the environment,

- Reduce greenhouse gas emissions through methods other than renewable energy generation and energy efficiency, such as electricity generated from nuclear sources,

- Reduce or eliminate the creation of waste materials; collect, reuse, remanufacture, recycle, or compost waste materials or wastewater.

4. Natural resources conservation. Products and services that conserve natural resources (e.g. organic agriculture and sustainable forestry, land management, soil, water, or wildlife conservation, stormwater management, etc.).

5. Environmental compliance, education and training, and public awareness. These are products and services that:

- Enforce environmental regulations,

- Provide education and training related to green technologies and practices,

- Increase public awareness of environmental issues.

ii. Business activities that use more environment-friendly
Table 8 (continued)

General type of green business activities

Detailed groups of green business activities

production processes or use fewer natural resources than their peers

fuel from renewable sources (e.g. wind, biomass, geothermal, solar, ocean, hydropower, landfill gas and municipal solid waste, etc.), primarily for use within the establishment.

2. Energy efficiency. Using technologies and practices to improve energy efficiency within the establishment (e.g. cogeneration - combined heat and power).

3. Pollution reduction and removal, greenhouse gas reduction, and recycling and reuse. Using technologies and practices within the establishment to:

- Reduce or eliminate creation or release of pollutants or toxic compounds, or remove pollutants or hazardous waste from the environment,

- Reduce greenhouse gas emissions through methods other than renewable energy generation and energy efficiency,

- Reduce or eliminate the creation of waste materials; collect, reuse, remanufacture, recycle, or compost waste materials or wastewater.

4. Natural resources conservation. Using technologies and practices within the establishment to conserve natural resources (e.g. organic agriculture and sustainable forestry, land management, soil, water, or wildlife conservation, stormwater management, etc.).

categorization of green jobs). BLS distinguishes two types of green business activities: (i) businesses that produce goods or provide services that benefit the environment or conserve natural resources and (ii) businesses that use more environment-friendly production processes or use fewer natural resources than their peers. Each of the two types comprises a list of activities that characterize it. A detailed overview of green business activities is provided in Table. 
The classification was carried out following a predefined procedure in order to obtain reliable and robust results. First, two researches manually and independently conducted a survey of the websites (when available) of the companies in the dataset, and based on the BLS definition identified green businesses. Second, the outcomes of the two classifications were compared, and matching firms were confirmed. Finally, the mismatches were independently checked by the third researcher (also via websites), who made the concluding decision. We identified 62 out of 361 start-ups as green (approximately $17 \%$ ).

\section{Appendix C: Univariate tests between green and non-green ventures}

We report univariate Wald tests between green and non-green ventures to assess whether among the variables of interest any significant difference exists. In Table 9, green ventures show a larger founding team, with a lower percentage of active founders. These features seem to be positively correlated with venture success. As highlighted by the extant literature (Beck and Demirguc-Kunt 2006), business size is negatively correlated with obstacles to venture growth and access to external finance. Further, a lower percentage of active founders may lead to less horizontal agency costs within teams (Colombo et al. 2014), and thus to better venture performance. Green ventures are more likely to have founders with technical education attainments in their founding teams than non-green businesses $(+31 \%)$. As expected, green ventures are less likely to have at least a founder with previous experience in the same industry than non-green ones $(-12 \%)$. Conversely, green entrepreneurs are more likely to have previous business experience in other sectors than non-green entrepreneurs $(+15 \%)$. Green ventures are more likely than non-green ones to be incubated $(+19 \%)$ or to bear as academic spin-outs $(+35 \%)$. While $10 \%$ of our sample green ventures have a corporate shareholding, less than $4 \%$ of non-green ventures are minority owned by a corporate investor at foundation.

Table 9 Univariate $t$ tests

\begin{tabular}{lccc}
\hline Variable & Non-green & Green & Non-green vs. green \\
\hline OpFounders & 1.205 & 1.3493 & -0.1443 \\
OpFounders_Founders & 0.8824 & 0.8235 & 0.0589 \\
TechEducation & 0.4726 & 0.7833 & -0.3107 \\
EcoEducation & 0.1473 & 0.0833 & 0.0640 \\
SpecWorkExp & 0.4555 & 0.3333 & 0.1222 \\
OtherWorkExp & 0.661 & 0.8167 & -0.1557 \\
FuctionalHeterogeneity & 0.3296 & 0.325 & 0.0046 \\
SerialManager & 0.4521 & 0.4667 & -0.0146 \\
Patent & 0.0788 & 0.1 & -0.0212 \\
Incubated & 0.1575 & 0.35 & -0.1925 \\
ASU & 0.1267 & 0.4833 & -0.3566 \\
SubsBeforeVC & 0.0582 & 0.1167 & -0.0585 \\
DebtFound & 0.1233 & 0.0667 & 0.0566 \\
CorporateShareFound & 0.0377 & 0.1 & -0.0623 \\
FoundYear & 1998.137 & 1999.9 & -1.7630 \\
Manufacturing & 0.4726 & 0.5833 & -0.1107 \\
\hline
\end{tabular}

$* p<0.10, * * p<0.05, * * * p<0.01$. We report the mean value of the variable of non-green and green ventures, and the Wald test on the difference between such values 


\section{Appendix D: Alternative exclusion restriction}

As robustness check, we use an alternative exclusion restriction: the cross-region variation in laws implemented by local governments to foster green innovations over time. This exclusion restriction is in line with the idea of policy-inducement dynamics developed by Porter and van der Linde (1995). The authors argue that "properly designed environmental standards can trigger innovation that may partially or more than fully offset the costs of complying with them" (p. 98). Hence, properly designed green local policies may positively associate with the presence of local green ventures (see also Dowell and Muthilingam 2017). We checked the institutional website of each Italian region and we collected data on every law implemented from 2008 backwards to foster the production/provision of green goods/ services or production processes that are environmentfriendly. Some examples are the Law 29 (Dec. 2008) implemented in Calabria region to foster the energy production from renewable sources, the Law 23 (Dec. 2004) implemented in Emilia-Romagna region to discipline the local production of energy, or the Law 11 (Dec. 2006) implemented in Lombardy region to reduce polluting emissions. Because of the crosssection nature of our analysis, for each venture, the above exclusion restriction takes value one if the regional government where the venture operates implemented a green law before venture foundation. This is a conservative assumption that allows us to not overestimate the potential signaling effect of green businesses on access to $\mathrm{VC}$ finance. It is worth noting that the use of changes in local regulation/legislation as instrument relates to changes that could involve both target-setting and subsidies, that is, these changes should simultaneously affect the demand for green innovation and the VC supply for green technologies. These results are fully in line with the main ones in Table 5 and are shown in Table 10.

Table 10 econometric baseline results with the cross-regional variation in laws as exclusion restriction

\begin{tabular}{lc}
\hline & \multicolumn{1}{l}{ IV } \\
\hline Green & 0.7433 \\
& $(0.5353)$ \\
OpFounders & -0.0240 \\
& $(0.0956)$
\end{tabular}

Table 10 (continued)

\begin{tabular}{|c|c|}
\hline & IV \\
\hline OpFounders_Founders & $\begin{array}{c}0.0575 \\
(0.0897)\end{array}$ \\
\hline TechEducation & $\begin{array}{c}0.0038 \\
(0.0629)\end{array}$ \\
\hline EcoEducation & $\begin{array}{c}0.1009 \\
(0.0822)\end{array}$ \\
\hline SpecWorkExp & $\begin{array}{c}-0.1174 * * \\
(0.0515)\end{array}$ \\
\hline OtherWorkExp & $\begin{array}{l}-0.0930 \\
(0.0770)\end{array}$ \\
\hline FuctionalHeterogeneity & $\begin{array}{l}0.3522 * \\
(0.2084)\end{array}$ \\
\hline SerialManager & $\begin{array}{c}-0.0575 * * \\
(0.0250)\end{array}$ \\
\hline Patent & $\begin{array}{c}0.0432 \\
(0.0649)\end{array}$ \\
\hline Incubated & $\begin{array}{l}-0.0122 \\
(0.0532)\end{array}$ \\
\hline ASU & $\begin{array}{l}-0.0813 \\
(0.1099)\end{array}$ \\
\hline SubsBeforeVC & $\begin{array}{c}0.0102 \\
(0.0780)\end{array}$ \\
\hline DebtFound & $\begin{array}{c}0.0078 \\
(0.0538)\end{array}$ \\
\hline CorporateShareFound & $\begin{array}{c}0.2399 * * * \\
(0.0829)\end{array}$ \\
\hline FoundYear & $\begin{array}{c}0.0021 \\
(0.0015)\end{array}$ \\
\hline Manufacturing & $\begin{array}{l}-0.0201 \\
(0.0352)\end{array}$ \\
\hline \multicolumn{2}{|l|}{ FinancingSearch } \\
\hline $\begin{array}{l}\text { Number of observations } \\
\text { Pseudo } \mathrm{R}^{2}\end{array}$ & 361 \\
\hline Centered $\mathrm{R}^{2}$ & 0.5976 \\
\hline F-statistic first stage & $894.29 * * *$ \\
\hline
\end{tabular}

$* p<0.10, * * p<0.05, * * * p<0.01$. The dependent variable is the likelihood to get VC. Estimates are derived from an IV linear regression with region-clustered standard errors. The regression is estimated with an intercept term. Standard errors in round brackets

\section{Appendix E: Interaction effects}

We dig into the data and present three contingencies that moderate the association between green business 
propositions and the likelihood to get VC. Specifically, we focus on three specific characteristics of the ventures-i.e., the technical/scientific education of the founder(s), the origin of the firm as academic spin-out, and the presence of corporate shareholders into the venture's equity (operationalized by the variables TechEducation, ASU and CorporateShareFound) - to test their effect in making the green business proposition more or less attractive to VC investors. We estimate our probit model specification (as that in Table 5, column (2)) including one-by-one an additional contingency effect, i.e., interacting the focal moderating variable with the variable Green. In this setting, given the dichotomous nature of our dependent variable, the effects of these interaction terms must be investigated over the full range of covariate values through graphical techniques (Ai and Norton 2003; Hoetker 2007).

Figure 1 reveals that TechEducation negatively moderates the likelihood for a venture to get $\mathrm{VC}$, that is having at least one of the founders with a bachelor degree in technical/scientific subjects helps getting VC in non-green businesses, but this effect vanishes in green ventures. This can be explained looking at Table 9. On average, the presence of founders with a bachelor degree in technical/scientific subjects is more likely in green ventures because of their higher complexity. Thus, having technically educated founders is a more powerful signal for non-green businesses.

Conversely, we find a positive moderation effect of the variable $A S U$ on the venture's likelihood to access VC (as shown in Fig. 2). This may be interpreted as follows: if we assume that green businesses are more difficult to assess for $\mathrm{VCs}$, the link with a research institution makes possible for the venture the use of labs and research academic personnel, and the exposure to cutting-edge basic research technologies. This may lead to a faster technology development and thus to a better business outcome.

In the same way, Fig. 3 shows that the moderation of CorporateShareFound is positive suggesting that having a corporate shareholder in the venture's equity at foundation is very important for green businesses (and not for other ventures). As above, if we assume that green businesses are more difficult to assess for an external investor, the presence of a corporate shareholder is a kind of "stamp of approval" of the technical feasibility and commercial potential of the venture's business model.

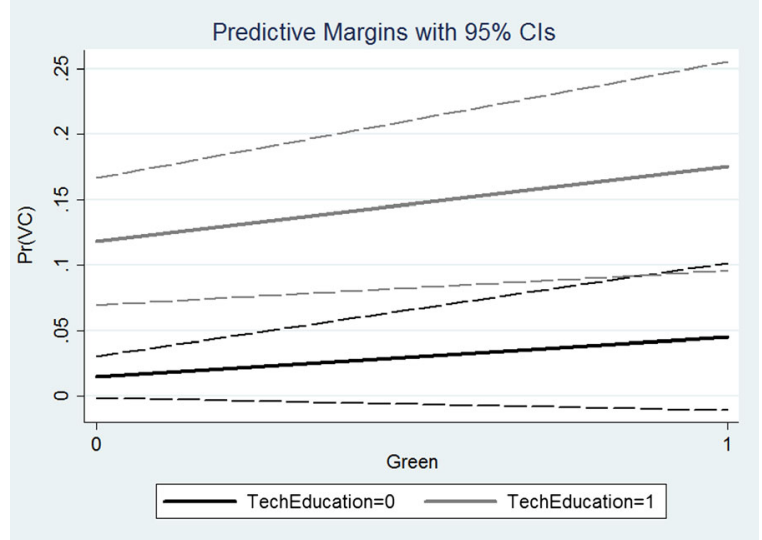

Fig. 1 The moderating role of TechEducation

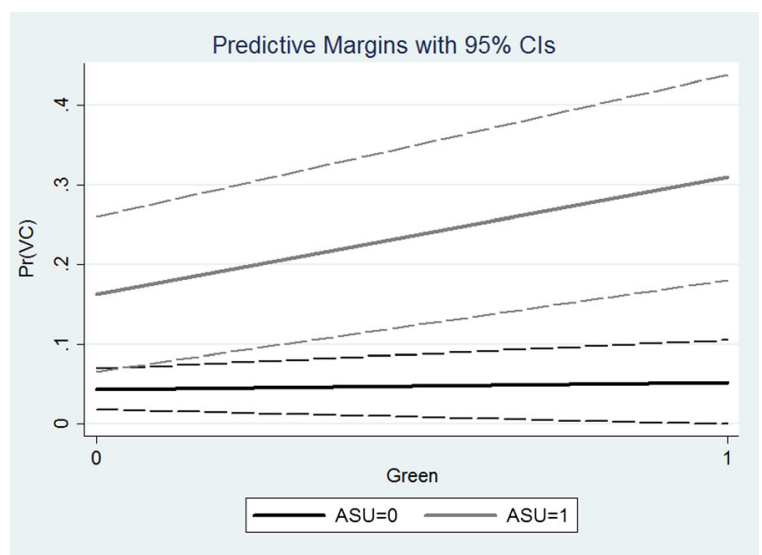

Fig. 2 The moderating role of $A S U$

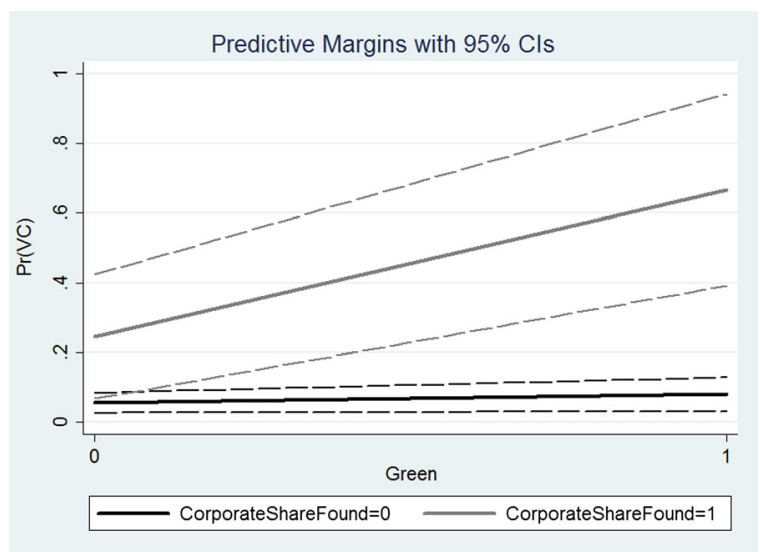

Fig. 3 The moderating role of CorporateShareFound 
Open Access This article is distributed under the terms of the Creative Commons Attribution 4.0 International License (http:// creativecommons.org/licenses/by/4.0/), which permits unrestricted use, distribution, and reproduction in any medium, provided you give appropriate credit to the original author(s) and the source, provide a link to the Creative Commons license, and indicate if changes were made.

\section{References}

Acemoglu, D., Johnson, S., \& Robinson, J. A. (2005). The rise of Europe: Atlantic trade, institutional change and economic growth. American Economic Review, 95(3), 546-579.

Ai, C., \& Norton, E. (2003). Interaction terms in logit and probit models. Economics Letters, 80(1), 123-129.

Ambec, S., \& Lanoie, P. (2008). Does it pay to be green? A systematic overview. Academy of Management Perspectives, 22(4), 45-62.

Amore, M. D., \& Bennedsen, M. (2016). Corporate governance and green innovation. Journal of Environmental Economics and Management, 75, 54-72.

Angrist, J. D., \& Pischke, J.-S. (2008). Mostly harmless econometrics: An empiricist's companion. Princeton: Princeton university press.

Audretsch, D. B. (1995). Innovation and industry evolution. Cambridge: MIT press.

Ayyagari, M., Demirgüç-Kunt, A., \& Maksimovic, V. (2011). Firm innovation in emerging markets: The role of finance, governance, and competition. Journal of Financial and Quantitative Analysis, 46(6), 1545-1580.

Bamberger, P., Bacharach, S., \& Dyer, L. (1989). Human resources management and organizational effectiveness: High technology entrepreneurial startup firms in Israel. Human Resource Management, 28(3), 349-366.

Baum, J. A. C., \& Silverman, B. S. (2004). Picking winners or building them? Alliance, intellectual, and human capital as selection criteria in venture financing and performance of biotechnology startups. Journal of Business Venturing, 19(3), 411-436.

Beck, T., \& Demirguc-Kunt, A. (2006). Small and medium-size enterprises: Access to finance as a growth constraint. Journal of Banking \& Finance, 30(11), 2931-2943.

Benabou, R., Ticchi, D., \& Vindigni, A. (2015). Religion and innovation. American Economic Review, 105(5), 346-351.

Berle, G. (1991). The green entrepreneur: Business opportunities that can save the Earth make you money. Blue Ridge Summit: Liberty Hall Press.

Bocken, N. M. P. (2015). Sustainable venture capital - catalyst for sustainable start-up success? Journal of Cleaner Production, 108, 647-658.

Brechin, S. R. (1999). Objective problems, subjective values, and global environmentalism: Evaluating the postmaterialist argument and challenging a new explanation. Social Science Quarterly, 80, 793-809.

Bruderl, J., Preisendorfer, P., \& Ziegler, R. (1992). Survival chances of newly founded business organizations. American Sociological Review, 57(2), 227-242.
Bürer, M. J., \& Wüstenhagen, R. (2009). Which renewable energy policy is a venture capitalist's best friend? Empirical evidence from a survey of international cleantech investors. Energy Policy, 37(12), 4997-5006.

Carpenter, R. E., \& Petersen, B. C. (2002). Capital market imperfections, high-tech investment, and new equity financing. The Economic Journal, 112(477), F54-F72.

Chen, F., Hope, O.-K., Li, Q., \& Wang, X. (2011). Financial reporting quality and investment efficiency of private firms in emerging markets. Accounting Review, 86(4), 1255-1288.

Cohen, B., \& Winn, M. I. (2007). Market imperfections, opportunity and sustainable entrepreneurship. Journal of Business Venturing, 22(1), 29-49.

Cohen, W. M., \& Levinthal, D. A. (1990). Absorptive Capacity : A new perspective on learning and innovation. Administrative Science Quarterly, Special Issue: Technology, Organization, and Innovation, 35(1), 128-152.

Colombo, M. G., Croce, A., \& Murtinu, S. (2014). Ownership structure, horizontal agency costs and the performance of high-tech entrepreneurial firms. Small Business Economics, $42(2), 265-282$.

Colombo, M. G., Grilli, L., \& Murtinu, S. (2011). R\&D subsidies and the performance of high-tech start-ups. Economics Letters, 112(1), 97-99.

Colombo, M. G., Grilli, L., Murtinu, S., Piscitello, L., \& Piva, E. (2009). Effects of international R\&D alliances on performance of high-tech start-ups: A longitudinal analysis. Strategic Entrepreneurship Journal, 3(4), 346-368.

Connelly, B., Certo, S., Ireland, R. D., \& Reutzel, C. R. (2011). Signaling theory: A review and assessment. Journal of Management, 37(1), 39-67.

Cooper, A. C., Gimeno-Gascon, F. J., \& Woo, C. Y. (1994). Initial human and financial capital as predictors of new venture performance. Journal of Business Venturing, 9(5), 371-395.

Criscuolo, C., \& Menon, C. (2015). Environmental policies and risk finance in the green sector: Cross-country evidence. Energy Policy, 83, 38-56.

Croce, A., Marti, J., \& Murtinu, S. (2013). The impact of venture capital on the productivity growth of European entrepreneurial firms: "Screening" or "value added" effect? Journal of Business Venturing, 28(4), 489-510.

Cumming, D., Henriques, I., \& Sadorsky, P. (2013). "Cleantech" Venture Capital Around the World. SSRN Electronic Journal, No. 2323589.

Czarnitzki, D., Hall, B. H., \& Hottenrott, H. (2014). Patents as Quality for Financing Constraints on R\&D. DICE Discussion Paper, No. 133.

Dangelico, R. M., \& Pontrandolfo, P. (2010). From green product definitions and classifications to the green option matrix. Journal of Cleaner Production, 18(16-17), 1608-1628.

Dangelico, R. M., \& Pujari, D. (2010). Mainstreaming green product innovation: Why and how companies integrate environmental sustainability. Journal of Business Ethics, 95(3), 471-486.

Dean, T. J., \& McMullen, J. S. (2007). Toward a theory of sustainable entrepreneurship: Reducing environmental degradation through entrepreneurial action. Journal of Business Venturing, 22(1), 50-76.

Deaton, A. (2008). Income, health, and well-being around the world: Evidence from the Gallup world poll. The Journal of Economic Perspectives, 22(2), 53-72. 
del-Palacio, I., Zhang, X. T., \& Sole, F. (2012). The capital gap for small technology companies: Public venture capital to the rescue? Small Business Economics, 38(3), 283-301.

Demirel, P., \& Kesidou, E. (2011). Stimulating different types of eco-innovation in the UK: Government policies and firm motivations. Ecological Economics, 70(8), 1546-1557.

Demirel, P., \& Parris, S. (2015). Access to finance for innovators in the UK's environmental sector. Technology Analysis \& Strategic Management, 27(7), 782-808.

Denis, D. J. (2004). Entrepreneurial finance: An overview of the issues and evidence. Journal of Corporate Finance, 10(2), 301-326.

Dixon, S. E. A., \& Clifford, A. (2007). Ecopreneurship - A new approach to managing the triple bottom line. Journal of Organizational Change Management, 20(3), 326-345.

Dowell, G., \& Muthilingam, S. (2017). Will firms go green if it pays? The impact of disruption, cost, and external factors on the adoption of environmental initiatives. Strategic Management Journal, 38(6), 1287-1304.

Dunlap, R. E., \& Mertig, A. G. (1997). Global environmental concern: An anomaly for postmaterialism. Social Science Quarterly, 78(1), 24-29.

Esty, D., \& Winston, A. (2009). Green to gold: How smart companies use environmental strategy to innovate, create value, and build competitive advantage. Hoboken: John Wiley \& Sons.

EVCA. (2015). 2014 European Private Equity Activity: Statistics on Fundraising, Investments \& Divestments. Brussels, Belgium.

Florin, J., Lubatkin, M., \& Schulze, W. (2003). A social capital model of high-growth ventures. Academy of Management Journal, 46(3), 374-384.

Ghosh, S., \& Nanda, R. (2010). Venture Capital Investment in the Clean Energy Sector. HBS Working Paper 11-020.

Gimmon, E., \& Levie, J. (2010). Founder's human capital, external investment, and the survival of new high-technology ventures. Research Policy, 39(9), 1214-1226.

Gompers, P. A., \& Lerner, J. (2001). The venture capital revolution. The Journal of Economic Perspectives, 15(2), 145-168.

Hall, B. H., \& Helmers, C. (2010). The Role of Patent Protection in (Clean/Green) Technology Transfer. NBER Working Paper Series, No. 16323.

Hall, B. H., \& Helmers, C. (2013). Innovation and diffusion of clean/green technology: Can patent commons help? Journal of Environmental Economics and Management, 66(1), 3351.

Hall, B. H., \& Lerner, J. (2010). Handbook of the economics of innovation. Handbook of the Economics of Innovation, 1(31), 609-639.

Hall, J. K., Daneke, G. A., \& Lenox, M. J. (2010). Sustainable development and entrepreneurship: Past contributions and future directions. Journal of Business Venturing, 25(5), 439-448.

Heil, O., \& Robertson, T. S. (1991). Toward a theory of competitive market signaling: A research agenda. Strategic Management Journal, 12, 403-418.

Hellmann, T. (2000). Venture capitalist: The coaches of Silicon Valley. In W. Miller, C. M. Lee, M. G. Hanock, \& H. Rowen (Eds.), The Silicon Valley edge: A habitat for innovation and entrepreneurship (pp. 267-294). Stanford: Stanford University Press.
Hockerts, K., \& Wüstenhagen, R. (2010). Greening goliaths versus emerging Davids - Theorizing about the role of incumbents and new entrants in sustainable entrepreneurship. Journal of Business Venturing, 25(5), 481-492.

Hoetker, G. (2007). The use of logit and Probit models in strategic management research: Critical issues. Strategic Management Journal, 28(4), 331-343.

Hoogendoorn, B., Guerra, D., \& van der Zwan, P. (2015). What drives environmental practices of SMEs? Small Business Economics, 44(4), 759-781.

Hsu, D. H., \& Ziedonis, R. H. (2008). Patents As Quality Signals for Entrepreneurial Ventures. Academy of Management Annual Meeting Proceedings, 2008(1), 1.

Kaplan, S. N., \& Lerner, J. (2016). Venture Capital Data: Opportunities and Challenges. In Measuring Entrepreneurial Businesses: Current Knowledge and Challenges. University of Chicago Press.

Kesidou, E., \& Demirel, P. (2012). On the drivers of eco-innovations: Empirical evidence from the UK. Research Policy, 41(5), 862-870.

Kirzner, I. M. (1997). Entrepreneurial discovery and the competitive market process: An Austrian approach. Journal of Economic Literature, 35(1), 60-85.

Klepper, S. (2001). Employee startups in high-tech industries. Industrial and Corporate Change, 10(3), 639-674.

Knight, E. R. W. (2010). The Economic Geography of Clean Tech Venture Capital. SSRN Electronic Journal, No. 1588806.

Lerner, J. (1999). The government as venture capitalist: The longrun impact of the SBIR program. The Journal of Business, $72(3), 285-318$.

Martin, R., Sunley, P., \& Turner, D. (2002). Taking risks in regions: The geographical anatomy of Europe's emerging venture capital market. Journal of Economic Geography, 2(2), 121-150.

Meek, W. R., Pacheco, D. F., \& York, J. G. (2010). The impact of social norms on entrepreneurial action: Evidence from the environmental entrepreneurship context. Journal of Business Venturing, 25(5), 493-509.

Meuleman, M., \& Maeseneire, W. D. (2012). Do R\&D subsidies affect SMEs' access to external financing? Research Policy, 41(3), 580-591.

Meyskens, M., \& Carsrud, A. L. (2013). Nascent greentechnology ventures: A study assessing the role of partnership diversity in firm success. Small Business Economics, 40(3), 739-759.

Migendt, M., Täube, F. A., von Flotow, P., \& Gilbert, B. A. (2013). Emergence of Cleantech as an Investment Category? Public Discourse and Venture Capital Investment. In 35th DRUID Celebration Conference.

Miller, D. (1983). The correlates of entrepreneurship in three types of firms. Management Science, 29(7), 770-791.

Mosey, S., \& Wright, M. (2007). From human capital to social capital: A longitudinal study of technology-based academic entrepreneurs. Entrepreneurship Theory and Practice, 31(6), 909-935.

Nahata, R. (2008). Venture capital reputation and investment performance. Journal of Financial Economics, 90(2), 127151.

Ottman, J. A., Stafford, E. R., \& Hartman, C. L. (2006). Avoiding green marketing myopia: Ways to improve consumer appeal for environmentally preferable products. Environment: 
Science and Policy for Sustainable Development, 48(5), 2236.

Pacheco, D. F., Dean, T. J., \& Payne, D. S. (2010). Escaping the green prison: Entrepreneurship and the creation of opportunities for sustainable development. Journal of Business Venturing, 25(5), 464-480.

Parrish, B. D. (2010). Sustainability-driven entrepreneurship: Principles of organization design. Journal of Business Venturing, 25(5), 510-523.

Peterson, M. F., \& Roquebert, J. (1993). Success patterns of Cuban-American enterprises: Implications for entrepreneurial communities. Human Relations, 46(8), 921-937.

Petkova, A. P., Wadhwa, A., Yao, X., \& Jain, S. (2011). Being first or making a difference? A study of U.S venture capital investments into the "clean" energy sector. Frontiers of Entrepreneurship Research, 31(2), 49-61.

Petkova, A. P., Wadhwa, A., Yao, X., \& Jain, S. (2014). Reputation and decision making under ambiguity: A study of U.S. venture capital firms' Investments in the Emerging Clean Energy Sector. Academy of Management Journal, $57(2), 422-448$.

Porter, M., \& van der Linde, C. (1995). Green and competitive: Ending the stalemate. Harvard Business Review, 73(5), 120134.

Roy, R., Wield, D., Gardiner, J. P., \& Potter, S. (1996). Innovative product development. Milton Keynes: The Open University.

Samila, S., \& Sorenson, O. (2011). Venture capital, entrepreneurship, and economic growth. The Review of Economics and Statistics, 93(1), 338-349.

Santos, F. M., \& Eisenhardt, K. M. (2009). Constructing markets and shaping boundaries: Entrepreneurial power in nascent fields on JSTOR. The Academy of Management Journal, 52(4), 643-671.

Schertler, A., \& Tykvová, T. (2012). What lures cross-border venture capital inflows? Journal of International Money and Finance, 31(6), 1777-1799.
Schumpeter, J. A. (1934). The theory of economic development. Oxford: Oxford University Press.

Schumpeter, J. A. (1939). Business cycles: A theoretical, historical and statistical analysis of the capitalist process (Vol. 1). New York City: MacGraw-Hill.

Seibert, S. E., Kraimer, M. L., \& Liden, R. C. (2001). A social capital theory of career success. Academy of Management Journal, 44(2), 219-237.

Sine, W. D., \& Lee, B. H. (2009). Tilting at windmills? The environmental movement and the emergence of the U.S. wind energy sector. Administrative Science Quarterly, 54(1), 123-155.

Tamvada, J. P. (2009). Entrepreneurship and welfare. Small Business Economics, 34(1), 65-79.

United Nations Framework Convention on Climate Change. (2006). Application of environmentally sound technologies for adaptation to climate change. Bonn.

Westhead, P., Ucbasaran, D., \& Wright, M. (2005). Decisions, actions, and performance: Do novice, serial, and portfolio entrepreneurs differ? Journal of Small Business Management, 43(4), 393-417.

Wiklund, J. (1999). The sustainability of the entrepreneurial orientation performance relationship. Entrepreneurship: Theory \& Practice, 24(1), 37-48.

Wooldridge, J. M. (2010). Econometric analysis of cross section and panel data. Boston: MIT press.

Wüstenhagen, R., \& Teppo, T. (2006). Do venture capitalists really invest in good industries? Risk-return perceptions and path dependence in the emerging European energy VC market. International Journal of Technology Management, 34(1/2), 63-87.

York, J. G., \& Venkataraman, S. (2010). The entrepreneur-environment nexus: Uncertainty, innovation, and allocation. Journal of Business Venturing, 25(5), 449-463.

Zahra, S. A. (1993). A conceptual model of entrepreneurship as firm behavior: A critique and extension. Entrepreneurship: Theory and Practice, 17(4), 5-22. 